\title{
ANALISIS PEMUNGUTAN PAJAK BUMI DAN BANGUNAN PERDESAAN DAN PERKOTAAN DI KECAMATAN MALALAYANG
}

\author{
Anastasia Graisa Enga ${ }^{1}$, Lintje Kalangi ${ }^{2}$, Jessy D.L. Warongan ${ }^{3}$ \\ ${ }^{1,2,3}$ Fakultas Ekonomi dan Bisnis, Jurusan Akuntansi, Universitas Sam Ratulangi, Jl. Kampus Bahu, Manado, \\ 95115, Indonesia \\ E-mail: engagraisa@gmail.com
}

\begin{abstract}
Rural and Urban Land and Building Tax is a tax on land and/or buildings owned, controlled, and/or utilized by individuals or entities, except areas used for plantation, forestry and mining business activities. Management of land and building taxes is handed over to regional governments since the enactment of law number 28 of 2009 concerning regional taxes and regional levies. To improve the accountability of regional financial management, especially from UN revenues, no later than January 1, 2014.PBB-P2 transfer is expected to increase regional own-source revenues (PAD) and at the same time improve the structure of the regional income and expenditure budget (APBD). The purpose of this study was to find out and analyze the process of collecting rural and urban land and building tax (PBB-P2) in Malalayang District. The type of research conducted is descriptive qualitative research. The results showed that the PBB-P2 collection process in Malalayang District in general had gone well although there were still some obstacles, such as the lack of awareness in paying $P B B-P 2$ by taxpayers domiciled outside the region but having tax objects in the region, lack of available availability in PBB-P2 collection, different economic levels, also the absence of sanctions imposed by the government on taxpayers in paying taxes and lack of socialization from the local government. So that causes the target to be achieved has not met expectations in accordance with existing provisions.
\end{abstract}

Keywords: PBB-P2 Collection

\section{PENDAHULUAN}

Indonesia merupakan salah satu negara yang telah berkembang di dunia yang terus melakukan pembangunan di berbagai sektor diseluruh wilayah yang ada di indonesia. Untuk memenuhi kebutuhan pembiayaan pembangunan ini membutuhkan anggaran yang tidak sedikit.Pemerintah Indonesia melakukan pengoptimalisasian terhadap sumber penerimaan yang ada dinegara.Pada saat melakukan suatu pembangunan, setiap negara memerlukan biaya yang cukup besar oleh karena itu sumber biaya yang bisa diharapkan mengalami peningkatan salah satunya dapat berasal dari pajak.

Pajak adalah iuran pada negara (dapat dipaksakan) yang terutang oleh wajib pajak membayarnya (menurut peraturan-peraturan) dengan tidak mendapat prestasi kembali yang langsung dapat ditunjuk dan gunanya adalah untuk membiayai pengeluaran-pengeluaran umum berhubugan dengan tugas negara untuk menyelenggarakan pemerintahan. Widyaningsih (2011).

Pajak memiliki sumber utama yang tetap terhadap penerimaan negara yang sangat penting dalam melaksanakan atau meningkatkan pembangunan bagi kesejahteraan masyarakat.Kategori pajak terhadap pengelolaannya dapat dikelola oleh pemerintah pusat dan pajak yang dapat dikelola oleh pemerintah daerah. Pada tanggal 15 September 2009, telah disahkan Undang-Undang nomor 28 tahun 2009 sebagai pengganti Undang-Undang nomor 18 tahun 1997 dan Undang-Undang nomor 34 tahun 2000 tentang pajak daerah dan retribusi daerah secara efektif pada tanggal 1 Januari 2010. Latar belakang pembentukan undang- 
undang nomor 28 tahun 2009 (UU 28 2009) antara lain untuk memberikan kewenangan yang lebih besar kepada daerah dalam mengatur pajak daerah dan retribusi daerah, meningkatkan akuntabilitas dalam penyediaan layanan dan pemerintahan, memperkuat otonomi daerah, serta memberikan kepastian hukum bagi masyarakat dan dunia usaha.

Di Kecamatan Malalayang, pemerintah menjalankan pengelolaan atas pengalihan PBB-P2 pada 1 January 2014. Pelimpahan ini merupakan peluang dan tantangan tersendiri bagi pemerintahan yang ada di Kecamatan Malalayang. Berbagai persiapan yang telah dilakukan untuk pengalihan kewenangan PBB-P2 sebagai pajak daerah tidak hanya menyangkut soal pemungutan, tetapi menyangkut proses bagaimana penerimaan PBB-P2 dicatat dan dilaporkan secara akuntansi. Adanya pencatatan dan pelaporan merupakan hal yang sangat penting bagi pemerintah daerah dalam mengelola keuangan daerahnya secara akuntabel dan transparan sesuai dengan berlakunya peraturan perundang-undangan yang ada. Dalam pemungutan PBB-P2 perlu juga untuk kita ketahui bagaimana proses pemungutan yang dilakukan oleh pengelolah PBB-P2 di Kecamatan Malalayang.

Dalam menjalankan pemungutan PBB-P2 di Kecamatan Malalayang, permasalahan yang dihadapi yaitu masih kurangnya sosialisasi masalah mengenai pelaksanaan pemungutan PBB-P2 yang mengakibatkan para wajib pajak banyak yang kurang mengetahui tentang pelaksanaan pemungutan PBB-P2.Hal ini sangat berpengaruh pada kesadaran wajib pajak dalam membayar dan juga melunasi pajak terutangnya secara tepat waktu atau setelah jatuh tempo. Masih juga terjadi tunggakan-tunggakan disetiap tahunnya dan masih ada wajib pajak yang tidak membayar atau melunasi pajak terutangnya sehingga mengakibatkan realisasi penerimaan PBB-P2 belum bisa mencapai target yang telah ditetapkan.

\section{TINJAUAN PUSTAKA}

Akuntansi. Arens et,al., (2015) akuntansi adalah pencatatan, pengklasifikasian dan pengiktisaran peristiwa-peristiwa ekonomi dengan cara yang logis yang bertujuan untuk menyediakan informasi keuangan dalam pengambilan keputusan. Jadi akuntansi merupakan suatu proses mencatat, mengklasifikasian, meringkas, mengelola dan menyajikan data, transaksi serta kejadian yang berhubungan dengan keuangan sehingga dapat dijadikan sebagai dasar pengambilan keputusan serta tujuan lainnya.Dalam buku "Intermediate Acounting" Syakur (2015), american insitute of certified public accounting (AICPA) mendefinisikan "Akuntansi sebagai suatu seni pencatatan, penggolongan, dan pengikhtisaran dengan cara tertentu dan dalam ukuran moneter transaksi dan kejadian-kejadian yang umumnya bersifat keuangan dan termasuk menafsirkan hasil-hasilnya".

Pajak. Mardiasmo (2016) pajak adalah iuran rakyat kepada kas negara berdasarkan undang-undang (yang dapat dipaksakan) dengan tidak mendapatkan jasa timbal balik (kontrasepsi) yang langsung dapat ditunjukkan, dan yang digunakan untuk membayar pengeluaran umum. Definisi tersebut disempurnakan menjadi: "Pajak adalah peralihan kekayaan dari pihak rakyat kepada kas negara untuk membiayai pengeluaran rutin dan "surplus"-nya digunakan untuk public saving yang merupakan sumber utama untuk membiayai public investment". Harnanto (2013) menyatakan pajak adalah pembayaran atau pembebanan yang tidak secara langsung berhubungan dengan barang/jasa yang berada dalam wilayah atau dalam jangkauan pemerintah.

Akuntansi Perpajakan. Waluyo (2014) ialah "dalam menetapkan besarnya pajak terhutang tetap mendasarkan pada laporan keuangan yang disusun oleh perusahaan, mengingat tentang perundang-undangan perpajakan terdapat aturan-aturan khusus yang berkaitan dengan akuntansi, yaitu masalah konsep transaksi dan peristiwa keuangan, metode pengukurannya, serta pelaporan yang ditetapkan dengan undang-undang". Agoes (2014) akuntansi pajak ialah akuntansi yang diterapkan sesuai dengan peraturan perpajakan yang disebut dengan akuntansi pajak. 
Pajak Bumi dan Bangunan Perdesaan dan Perkotaan (PBB-P2).Peraturan Menteri Keuangan dan Menteri dalam Negeri No.213/PMK.072010 dan No.58 tahun 2010 dalam Munawaroh et.al., (2014) PBB-P2 adalah pajak atas bumi dan bangunan yang dimiliki, dikuasai dan atau dimanfaatkan oleh orang pribadi atau badan, kecuali kawasan yang digunakan untuk kegiatan usaha perkebunan, perhutanan dan pertambangan.

Penelitian Terdahulu. Napitupulu \& Budiarso (2015) menemukan bahwa penerapan pemungutan PBB-P2 di Kota Manado sudah terbilang cukup memuaskan. Wardani \& Fadhlia (2017) menemukan bahwa dari segi efektivitas tingkat penerimaan PBB-P2 dikategorikan sangat efektif. Sedangkan dari segi kontribusi masih sangat kurang dalam penerimaannya. Lubis (2018) menemukan bahwa beberapa masalah yang menjadi kendala yaitu tidak tercapainya target penerimaan pajak bumi dan bangunan pada angka realisasinya yang dicapai berada dibawah 81\%-94\%. Malomis \& Wangkar (2015) menemukan bahwa penerapan pemungutan PBB-P2 di Kota Tomohon belum berjalan dengan baik, karena ini merupakan tahun pertama dalam pemungutan sehingga masih banyak kekurangan dan hambatan yang terjadi selama pemungutan PBB-P2. Saputri et.al., (2015) menemukan bahwa masih banyak kendala yang terjadi di kabupaten pamekasan seperti, kurangnya komunikasi, ketersediaan SDM yang masih minim dan sarana yang dimiliki masih sangat terbatas sehingga menghambat pelaksanaan pemungutan $\mathrm{PBB}-\mathrm{P} 2$.

\section{METODE PENELITIAN}

Penelitian ini menggunakan metode deskriptif kualitatif yang dilakukan di Kecamatan Malalayang yang berlokasi di Jalan Mogandi Kelurahan Malalayang Satu Manado.Waktu penelitian dilaksanakan pada bulan Agustus sampai selesai. Penelitian ini menggunakan metode penelitian lapangan, wawancara, observasi dan dokumentasi. Metode analisis ini digunakan untuk mendeskripsikan proses pelaksanaan pemungutan PBB-P2 di Kecamatan Malalayang.

\section{HASIL PENELITIAN DAN PEMBAHASAN}

\subsection{Hasil Penelitian}

Pelaksanaan Pemungutan Pajak Bumi dan Bangunan Pedesaan dan Perkotaan (PBB-P2) Di Kecamatan Malalayang.Hasil wawancara mengenai Pelaksanaan Pemungutan Pajak Bumi dan Bangunan Perdesaan dan Perkotaan di Kecamatan Malalayang memiliki beberapa tahapan penting dalam hal pemungutan PBB-P2, sebagai berikut:

1. Pendaftaran : pendaftaran objek PBB-P2 dilakukan oleh subjek pajak di Kecamatan Malalayang dengan cara mengambil formulir Surat Pemberitahuan Objek Pajak (SPOP) yang merupakan sarana bagi Wajib Pajak (WP) untuk mendaftarkan Objek Pajak yang akan dipakai sebagai dasar untuk menghitung Pajak Bumi dan Bangunan Perdesaan dan Perkotaan (PBB-P2). Kemudian wajib pajak harus mengisi formulir SPOP tersebut secara jelas, benar, lengkap dan tepat waktu.Selanjutnya ada syarat-syarat penting yang harus dipenuhi oleh wajib pajak seperti sket atau denah objek pajak, fotokopi KTP dan NPWP (bagi yang mempunyai NPWP), fotokopi sertifikat tanah dan foto kopi bukti kepemilikian (akta jual beli tanah) agar supaya menyatakan bahwa milik sendiri.Hasil dari SPOP itu, kemudian menerbitkan SPPT mengenai besarnya pajak yang harus dibayar oleh wajib pajak.SPPT diisi oleh petugas pajak, kemudian diberikan kepada wajib pajak. SPPT ini digunakan untuk memberitahukan pada wajib pajak tentang pengenaan PBB-P2 yang didalamnya berisikan antara lain nama serta alamat wajib pajak, data mengenai objek pajak, besarnya pajak terutang, tempat pembayaran dan jatuh tempo pembayaran.

2. Pendataan: tahap yang berikut adalah tahap pendataan. Proses pendataan dari hasil wawancara, yang dilaksanakan di Kecamatan Malalayang menggunakan formulir SPOP dan dilakukan sekurang-kurangnya untuk satu wilayah administrasi desa atau kelurahan. 
3. Penilaian: proses penilaian berdasarkan hasil wawancara sudah sangat baik dan sudah sesuai dengan ketentuan yang ada. Penilaian berfungsi untuk menilai objek pajak berupa tanah maupun bangunan yang dimiliki wajib pajak dan untuk menentukan NJOP sebagai dasar pengenaan PBB-P2.Syarat penting yang harus disediakan oleh wajib pajak ialah Sertifikat (Bukti Kepemilikan) dan harus disahkan dari Kantor Lurah.Begitu juga dengan pengukuran tanah harus ada tanda tangan dari Lurah dan tanda tangan dari 2 saksi.Berdasarkan itu saja wajib pajak sudah memiliki dasar untuk lanjut berkas. Untuk itu dari pemerintah meminta perhatian kepada wajib pajak agar lebih diperjelas dalam memberikan informasi yang lebih akurat dan terpercaya, agar bisa dinilai dengan baik sesuai prosedur yang ada.Mengingat jumlah objek pajak yang ada di Kecamatan Malalayang sangat banyak sedangkan jumlah tenaga atau petugas penilai dan waktu penilaian dilakukan yang tersedia sangatlah terbatas.

4. Penetapan: dari hasil wawancara bagian PBB-P2 di Kecamatan Malalayang, proses penetapan mendata SPPT dari bagian pengolahan data dan informasi kemudian melakukan perhitungan, penetapan dan pembebanan PBB-P2 terutang yang hasilnya dituangkan ke dalam SPPT. Kemudian mengadministrasikan SPPT tersebut dan menyerahkan kepada wajib pajak.

5. Pembayaran: mengenai proses pembayaran $\mathrm{PBB}-\mathrm{P} 2$ yang ditunjuk dapat dilakukan pada Kantor Bapeda, Bank BNI, Kantor Pos terdekat dimana wajib pajak bertempat tinggal dan tempat pembayaran yang tercantum pada SPPT. Cara yang digunakan melalui tempat pembayaran Kantor Bapeda, Kantor Pos dan Bank wajib pajak datang ketempat tersebut yang berada dilingkungan tempat tinggal, kemudian melaporkan rekening yang digunakan untuk menampung dana pembayaran PBB-P2. Kemudian wajib pajak mendapatkan bukti pembayaran pajak berupa Surat Tanda Terima Setoran (STTS) PBBP2 dari Kantor Bapeda, Kantor Pos dan Bank tercantum pada SPPT atau mendapatkan Tanda Terima Sementara (TTS) dari petugas pemungut PBB-P2 yang tempat pembayarannya di Kelurahan atau Desa yang ditunjuk resmi. STTS merupakan surat atau blangko pembayaran yang dijadikan bukti bahwa wajib pajak telah melunasi PBB-P2. Pada formulir STTS terdapat rincian jumlah yang harus dibayar (termasuk denda $2 \%$ per bulannya) jika pembayarannya dilakukan pada bulan ke (setelah tanggal jatuh tempo) selama jangka waktu 24 bulan ( 2 tahun) dan harus ada tanda terima dan cap dari Kantor Bapeda, Kantor Pos dan Bank. Sebelumnya dari pihak Kecamatan Malalayang telah memberikan berita acara dimana adanya pernyataan dari wajib pajak untuk membayar sesuai dengan tanggal yang sudah ada didalam perjanjian.

6. Penagihan : penagihan yang dilakukan dari pihak Kecamatan Malalayang dan pihak Kelurahan dengan cara menghimbau dan memberitahukan kepada wajib pajak untuk lebih tanggap dalam melakukan pembayaran PBB-P2. Proses penagihan memiliki 3 syarat penting untuk diberikan kepada wajib pajak yang harus mereka ikuti dan taati yaitu ketentuan umum dalam penagihan, memberikan surat tagihan pajak daerah (STPD) dan juga memberikan jangka waktu pelaksanaan penagihan. Semua syarat yang sudah di terapkan harus diikuti oleh wajib pajak agar tidak terjadi kesalahan yang akan merepotkan bagi petugas dan wajib pajak.

7. Pengurangan: dari hasil wawancara yang didapat dari Kecamatan Malalayang bagian PBB tentang pengurangan akan diberikan kalau objek pajak tidak sesuai dengan SPPT dari segi ukuran salah, dari segi bangunan salah itu bisa dikurang sesuai dengan objek yang ada dan juga akan diberikan pengurangan khususnya kepada Veteran sesuai dengan undang-undang yang ada.

8. Pelayanan: jenis pelayanan yang dilakukan di Kecamatan Malalayang oleh petugas ialah Salinan SPPT/SKPD/STPD, Pembetulan PBB-P2, Pendaftaran Objek Pajak Baru, Mutasi 
Objek/Subjek Pajak, Keberatan PBB-P2, Pengurangan PBB-P2 Terutang, Pembatalan SPPT/SKPD/STPD, Restitusi/Kompensasi PBB-P2 dan Surat Keterangan NJOP.

Hambatan-hambatan dan Upaya-upaya yang dihadapi Kecamatan Malalayang dalam Pelaksanaan PBB-P2. Dari hasil wawancara yang diperoleh dari Kecamatan Malalayang bahwa menyatakan masih ada terdapat kendala atau hambatan yang terjadi, sehingga dapat mempengaruhi adanya hasil penerimaan PBB-P2. Beberapa permasalahan mendasar yang ditemui dalam pelaksanaan pemungutan PBB-P2 yang dilakukan oleh Kecamatan Malalayang yang bisa mempengaruhi hasil penerimaan PBB-P2 antara lain, sebagai berikut:

1. Hambatan yang terjadi pada saat melakukan pendaftaran untuk objek pajak baru terdapat pada persiapan atau pengumpulan berkas yang selalu dilupakan oleh wajib pajak yang tidak mempersiapkan dengan baik. Upaya yang dilakukan oleh petugas ialah memberitahukan dengan baik apa saja yang menjadi ketentuan dalam mendaftarkan objek pajak baru.

2. Pelaksanaan kegiatan penentuan dalam hal pendataan objek pajak yang mana petugas harus mendatangi wajib pajak untuk mencatat data objek pajak yang diperlukan dalam perhitungan, penetapan dan pembebanan pajak yang terutang. Upaya yang diambil oleh Kecamatan Malalayang dengan melakukan menghimbau, penyuluhan, lokakarya, seminar dan lain-lain yang sehubungan dengan pajak.

3. Dalam hal penilaian wajib pajak melupakan untuk menandatangani sertifikat atau bukti kepemilikan dari Lurah. Upaya yang dilakukan oleh para petugas memberitahukan dengan benar sesuai dengan peraturannya.

4. Untuk penetapan perhitungan PBB-P2 terdapat masalah keberatan. Dalam mengatasi masalah seperti itu upaya yang dilakukan ialah dengan pengurangan pembayaran atau perhitungan pajak dengan melalui prosedur tertentu, seperti: melalui perangkat desa, melampirkan SPPT, melampirkan foto kopi identitas diri.

5. Dalam hal pembayaran masih ada saja wajib pajak yang belum membayar atau melunasi pajak terutangnya yang sudah jatuh tempo. Untuk upaya yang diambil dikasihnya surat teguran kepada wajib pajak yang belum membayar pajak terutangnya.

6. Hambatan dalam penagihan ialah wajib pajak tidak memperhatikan atau melupakan tanggal jatuh temponya yang sudah tertera dalam SPPT yang diberikan sehingga terjadi tunggakan. Upaya yang dilakukan petugas memberikan himbauan dan memberitahukan wajib pajak untuk lebih memperhatikan tanggal jatuh temponya.

7. Untuk pengurangan wajib pajak belum merasa puas dan ingin meminta pengurangan untuk tanah dan bangunan mereka. Upaya dari petugas memberitahukan kepada wajib pajak bahwa pengurangan akan diberikan bagi mereka yang mengalami bencana alam dan akan diberikan khusus kepada Veteran karena sudah terdapat pada undang-undang.

8. Temuan dalam pelayanan terdapat pada wajib pajak dan sistem yang belum terupdate. Upaya yang dilakukan memberitahukan kepada wajib pajak untuk menjaga dengan baik kelengkapan berkasnya dan selalu mengupdate sistem yang ada di Kecamatan Malalayang.

9. Selalu terdapat tunggakan-tunggakan yang terjadi. upaya yang dilakukan oleh Kecamatan Malalayang yaitu dengan mengadakan penyuluhan, pemberian peringatan lewat media masa agar para penunggak mengetahui dan segera melunasi tunggakan tersebut. 
Target dan Realisasi Pemungutan Pajak Bumi dan Bangunan Perdesaan dan Perkotaan (PBB-P2) Di Kecamatan Malalayang. Tabel 1 menunjukkan bahwa dari tahun ke tahun realisasi penerimaan PBB-P2 di Kecamatan Malalayang mengalami penurunan yang sangat signifikan dan bisa saja mempengaruhi penerimaan PBB-P2.

Tabel 1. Target dan Realisasi PBB-P2

\begin{tabular}{crr}
\hline Tahun Anggaran & Target $(\mathbf{R p )}$ & Realisasi (Rp) \\
\hline 2014 & 4.111 .178 .510 & 4.110 .443 .012 \\
2015 & 4.900 .257 .196 & 3.620 .116 .490 \\
2016 & 4.758 .509 .321 & 4.267 .489 .113 \\
2017 & 5.090 .533 .019 & 3.811 .181 .731 \\
\hline Jumlah & $\mathbf{1 8 . 8 6 0 . 4 7 8 . 0 4 6}$ & $\mathbf{1 5 . 8 0 9 . 2 3 0 . 3 4 6}$ \\
\hline
\end{tabular}

Sumber : Kecamatan Malalayang, 2018

\subsection{Pembahasan}

Analisis Proses Pelaksanaan Pemungutan Pajak Bumi dan Bangunan Perdesaan dan Perkotaan (PBB-P2)

1. Pendaftaran :Hambatan yang dialami wajib pajak tidak mempersiapkan berkas dengan baik dan tidak mengisi formulir dengan benar, jelas, lengkap dan tepat waktu. Upaya yang dilakukan dari Pemerintah Kecamatan Malalayang melakukan himbauan dan memberitahukan kepada wajib pajak untuk lebih teliti pada saat melakukan proses pendaftaran.

2. Pendataan: Hambatan yang dialami pengumpulan data objek pajak yang seringkali terdapat perbedaan maupun kekurangan, sehingga bisa berpengaruh dalam proses pendataan untuk pembuatan objek pajak baru. Upaya yang dilakukan memberikan arahan untuk wajib pajak agar bisa lebih memperhatikan berkas-berkas yang akan dikumpulkan.

3. Penilaian : Hambatan yang dialami data-data yang dimasukkan tidak sesuai dan wajib pajak tidak melengkapi syarat yang sudah ditentukan oleh petugas yang ada di Kecamatan Malalayang. upaya yang dilakukan memberitahukan kepada wajib pajak untuk lebih teliti dalam mengumpulkan data-datanya agar bisa diproses dengan baik.

4. Penetapan: Hambatan yang dialami terdapat pada saat melakukan perhitungan, penetapan dan pembebanan PBB-P2 terutang. Upaya yang dilakukan memberikan himbauan agar lebih teliti pada saat melakukan perhitungan, penetapan dan pembebanan PBB-P2 agar bisa diproses dengan baik.

5. Pembayaran: Hambatan yang dialami rendahnya pemahaman wajib pajak tentang tata cara pembayaran PBB-P2, kurangnya kesadaran dari wajib pajak dan tingkat ekonomi yang menjadi alasan yang tepat. Upaya yang dilakukan memberitahukan kepada wajib pajak agar tidak melewati tanggal jatuh tempo pembayaran dengan mengingatkan dan mensosialisasi kembali tentang pentingnya melakukan pembayaran PBB-P2.

6. Penagihan: Hambatan yang dialami kurangnya kerjasama dan kesadaran dari wajib pajak. Upaya yang dilakukan dengan menghimbau dan memberitahukan kepada wajib pajak untuk lebih baik lagi dalam pembayaran PBB-P2 agar tidak diberikan surat teguran penagihan.

7. Pengurangan: Hambatan yang dialami terdapat pada saat pengukuran. Upaya yang dilakukan memberikan penjelasan kepada wajib pajak tentang tata cara pengurangan.

8. Pelayanan : Hambatan yang dialami wajib pajak sudah membayar PBB tetapi tidak ada dalam basis data PBB, SPPT Palsu, Data wajib pajak tidak terdaftar, Wajib pajak tidak dapat menunjukkan bukti pembayaran karena hilang disebabkan bencana banjir, SPPT Ganda dan Kesalahan NJOP per meter. Upaya yang dialami memberitahukan kembali 
kepada wajib pajak agar memperhatikan berkas-berkas yang penting dan tidak melakukan kesalahan yang akan merugikan.

\section{KESIMPULAN DAN SARAN}

\subsection{Kesimpulan}

Berdasarkan hasil penelitian dan pembahasan pada bab sebelumnya mengenai pemungutan pajak bumi dan bangunan perdesaan dan perkotaan (PBB-P2) di Kecamatan Malalayang, maka penulis menarik kesimpulan bahwa :

1. Pelaksanaan pemungutan pajak bumi dan bangunan perdesaan dan perkotaan (PBB-P2) di Kecamatan Malalayang sudah sesuai dengan aturan yang ada dan memiliki peranan yang sangat penting. Secara keseluruhan semua rencana kegiatan yang dilakukan oleh Pemerintah Kecamatan Malalayang sudah bisa dibilang sangatlah baik meskipun masih ada saja yang perlu di tingkatkan lagi dari segi pembayaran pemungutan PBB-P2.

2. Hambatan dan upaya yang dihadapi oleh Kecamatan Malalayang dalam pelaksanaan pemungutan pajak bumi dan bangunan perdesaan dan perkotaan (PBB-P2), yakni : kurangnya pengetahuan dalam hal pemungutan PBB-P2, tingkat ekonomi berbeda, kesadaran wajib pajak dalam melakukan pembayaran PBB-P2, kurangnya ketersediaan yang dimiliki dalam pemungutan PBB-P2, dan juga tidak adanya sanksi yang diterapkan oleh pemerintah kepada wajib pajak dalam pembayaran PBB-P2. Upaya yang dilakukan dalam pemungutan PBB-P2 ialah, melakukan penyeluhan, lokakarya, seminar sehubungan dengan pajak, dan menginformasikan lewat media massa kapan pengambilan SPPT dapat dimulai dan batas pembayarannya.

\subsection{Saran}

Berdasarkan penelitian yang telah dilakukan dan menganalisis data yang diperoleh, maka peneliti memberikan saran sebagai berikut :

1. Tingkat pengawasan dan kontrol terhadap pegawai di Kecamatan Malalayang dalam menjalankan sistem pemungutan pajak bumi dan bangunan juga perlu ditingkatkan lagi, agar supaya sistem dapat berjalan dengan baik dan juga target dapat dipenuhi dengan baik. Dengan melakukan pelatihan dan bimbingan kepada petugas pemungut pajak perlu dilakukan agar proses pemungutan dapat berjalan dengan baik.

2. Kesadaran wajib pajak dalam membayar pajak bumi dan bangunan sudah bisa berjalan dengan baik, namun masih perlu juga dukungan dari pemerintah setempat agar bisa melakukan sosialisai dan penyuluhan kembali kepada wajib pajak menyangkut pelaksanaan pemungutan PBB-P2 sebagai pajak daerah agar bisa mengalami peningkatan dengan baik.

3. Sebaiknya memberikan sanksi yang tegas kepada wajib pajak bagi mereka yang tidak melakukan pembayaran pajak sesuai dengan peraturannya. Dengan demikian semua proses pelaksanaan pemungutan PBB-P2 bisa terlaksana dengan baik adanya.

\section{DAFTAR PUSTAKA}

Agoes, S. (2014). Auditing Petunjuk Praktis Pemeriksaan Akuntan oleh Akuntan Publik. Edisi 5. Buku 1. Jakarta: Salemba Empat.

Arens, A. A., Elder, R. J. \& Beasley, M. S. (2015). Auditing dan Jasa Assurance Pendekatan Terintegrasi. Jilid 2. Edisi Lima Belas. Jakarta : Erlangga.

Harnanto. (2013). Perencanaan Pajak. Edisi Pertama. Yogyakarta : BPFE.

Napitupulu, L. C., \& Budiarso, N. (2015). Pajak Bumi dan Bangunan Perdesaan dan Perkotaan (PBB-P2) Sebagai Pajak Daerah dan Implikasinya Terhadap Pencatatan 
Akuntansi pada Pemerintahan Kota Manado. Jurnal Emba, 3(1), 463-472. https://ejournal.unsrat.ac.id/index.php/emba/article/view/7157.

Mardiasmo. (2016). Perpajakan. Edisi Terbaru 2016. Yogyakarta : Andi Offset.

Malomis, M. C., \& Wangkar, A. (2015). Analisis Pemungutan dan Pencatatan Akuntansi PBB Pedesaan dan Perkotaan (PBB-P2) Sebagai Pajak Daerah di Kota Tomohon. Jurnal Emba, $3(2)$, 103-113. https://ejournal.unsrat.ac.id/index.php/emba/article/view/8360/7931.

Munawaroh, S., Nuryantika, R., Rahayu, S., Sari, P. S., \& Rustiyaningsih. (2014). Dampak Pengalihan PBB-P2 menjadi Pajak Daerah Peluang dan Tantangan. Jurnal Riset Manajemen dan Akuntansi, 2(1), 9-13. http://portal.widyamandala.ac.id/jurnal/index.php/jrma/article/view/189.

Lubis, P. K. D. (2018). Analisis Penerimaan Pajak Bumi dan Bangunan Pada Dinas Pendapatan Daerah Kota Medan .Jurnal Akuntansi, Keuangan \& Perpajakan Indonesia (JAKPI), 6(1). https://jurnal.unimed.ac.id/2012/index.php/eua/article/viewFile/11167/9900.

Saputri, E., Hakim, A., \& Noor, I. (2015). Implementasi kebijakan pemungutan PBB-P2 di Kabupaten Pamekasan. Jurnal Ilmu Sosial dan Ilmu Politik, 4(3). https://publikasi.unitri.ac.id/index.php/fisip/article/view/124/159.

Syakur, A. S. (2015). Intermediate Accounting. Edisi Revisi. Jakarta : Pembuka Cakrawala.

Undang-Undang Republik Indonesia Nomor 28 Tahun 2009 tentang Pajak Daerah dan Retribusi Daerah. 15 September 2009. Lembaran Negara Republik Indonesia Tahun 2009 Nomor 130. Jakarta.

Undang-Undang Republik Indonesia Nomor 34 Tahun 2000 tentang Perubahan atas UndangUndang Republik Indonesia Nomor 18 Tahun 1997 tentang Pajak Daerah dan Retribusi Daerah. 21 November 2015. Lembaran Negara Republik Indonesia Nomor 4048. Jakarta.

Wardani, R. \& Fadhlia, W. (2017). Analisis efektivitas penerimaan Pajak Bumi dan Bangunan Perdesaan dan Perkotaan dan kontribusinya terhadap Pendapatan Asli Daerah di Kabupaten Aceh Besar. Jurnal Ilmiah Mahasiswa Ekonomi Akuntansi. 2(3). http://www.jim.unsyiah.ac.id/EKA/article/view/4039.

Waluyo. (2014). Perpajakan Indonesia. Edisi 12. Buku 1. Jakarta: Salemba Empat.

Widyaningsih, A. (2011). Hukum Pajak dan Perpajakan : Dengan Pendekatan Mind Map. Bandung : Alfabeta. 